UDC 658.562; 621.983.073

V. Vanko, DSc, Prof.,

O. Prikhodko

Lviv Polytechnic National University, 12 Bandery Str., Lviv, Ukraine, 79013; e-mail: vvm510@ukr.net

\title{
FORMING OF NORMATIVE REQUIREMENTS FOR MATRIX ASSESSMENT OF MANUFACTURING MACHINE-BUILDING PRODUCTS QUALITY
}

\begin{abstract}
В.М. Ванько, О.М. Приходько. Формування нормативних вимог для матричного оцінювання якості виробництва машинобудівної продукції. Виходячи з вимог чинних нормативних документів, обгрунтовано структуру системи управління якістю машинобудівного виробництва у вигляді чотирьох комплексних систем, котрі характеризують всі стадії життєвого циклу продукції. 3 метою покращання функціонування даної системи запропоновано поєднання матричного методу оцінювання якості продукції і послуг та аналізу ризиків через різні види та наслідки потенційних відмов у споживача (FMEA). Оскільки при цьому головну увагу приділяється групам процесів проектування, підготовки та власне виробництва продукції та, беручи до уваги специфіку реалізації запропонованої методики оцінювання якості процесів і процедур, головним аспектом вважається формування часткових еталонних матриць якості. Найперше наголошено на специфіці та умовах створення досліджуваних часткових матриць якості шляхом організації нарад експертів. Під час цих нарад також формуються пакети часткових еталонних матриць. Запропоновано загальний підхід для їхнього оформлення шляхом вибору відповідних значень стосовно елементів часткових еталонних матриць, виходячи з рекомендованого діапазону значень. В якості прикладу розглянуто аналіз основних виробничих процесів, які стосуються виробництва гільзи АЛ 0908.3012.2017 циліндра двигуна внутрішнього згорання СМД-14, котрі встановлюються на тракторах і комбайнах. Описано формування часткових досліджуваних і еталонних матриць для процесів лиття заготовок: вхідного контролю, підготування шихти, виготовлення заготовок гільз і виготовлення та дослідження проб. Представлено аналогічні матриці якості, котрі характеризують механічну обробку заготовок гільз циліндра: початкового опрацювання, завершальної обробки та вихідного контролю. На підставі наведених з виробництва чисельних даних проведено аналіз ймовірних ризиків на досліджуваних стадіях життєвого циклу гільз циліндра, котрі можуть призвести до погіршення якості даних ї гільз і, відповідно - до виходів з ладу вказаної аграрної техніки. Запропоновано шлях для вдосконалення нормативної документації щодо технології виробництва у вигляді нових документів для проведення виробничих нарад провідних спеціалістів, що гарантуватиме вдосконалення системи управління якістю машинобудівного виробництва, ефективнішу роботу його виробничих ділянок та покращання конкурентоздатності продукції.

Ключові слова: система управління якістю, FMEA-аналіз, пріоритетне число ризику, показний якості, часткова матриця якості, часткова еталонна матриця, гільза циліндра

V. Vanko, O. Prikhodko. Forming of normative requirements for matrix assessment of manufacturing machine-building products quality. Based on the requirements of current normative documents, the structure of system management of engineering production quality is substantiated in the form of four integrated systems, which characterize all stages of the product life cycle. In order to improve the functioning of this system, there is proposed a combination of matrix method of products and services quality evaluation and risk analysis through different types and consequences of potential customer's failures (FMEA). Since the main attention is paid to the groups of design, training and production processes and, taking into account the specifics of the implementation of the proposed technique for assessing the quality of processes and procedures, the main aspect is regarded to be the formation of partial standard quality matrices. It is firstly emphasized on the specifics and conditions of creation of the examined partial matrices of quality by organizing expert meetings. During these meetings, the packages of partial standard matrices are also formed. A general approach is proposed for their execution by choosing the appropriate values concerning the elements of partial standard matrices, based on the recommended range of values. As an example, there is considered the analysis of the main production processes related to the production of sleeve AL 0908.3012.2017 of the cylinder of internal combustion engines SMD-14 which are installed in tractors and combine harvesters. The formation of partial investigated and standard matrices for processes of casting blanks is described: input control, preparation of batches, manufacturing of sleeve blanks and
\end{abstract}

DOI: 10.15276/opu.2.55.2018.11

(C) 2018 The Authors. This is an open access article under the CC BY license (http://creativecommons.org/licenses/by/4.0/). 
manufacturing and testing of samples. The similar quality matrices are presented, which characterize mechanical processing of cylinder sleeve blanks: initial processing, final processing and output control. On the basis of multiple data presented in production, there is conducted the analysis of potential risks at the investigated stages of a life cycle of cylinder sleeves, which may lead to deterioration in quality of these sleeves and, accordingly, to failures of the specified agrarian machinery. The way to improve the normative documents on production technology in the form of new documents for conducting production meetings of leading specialists is proposed. This will ensure the improvement of the quality management system of machine-building production, the efficient operation of its production sites and the improvement of the competitiveness of products.

Keywords: quality management system, FMEA-analysis, priority number of risk, quality scores, partial quality matrix, partial reference matrix, cylinder sleeve

Introduction. Currently domestic machine-building enterprises are trying to constantly increase production volumes for own and international markets. Along with the necessity to provide an appropriate pricing policy for such products, it is equally important to guarantee its high quality in all aspects that are of interest to the consumer. To do this, one should optimally organize the operation of the enterprise and all its units, including the totality of production processes. Such a task is solved by means of a quality management system (QMS) for an enterprise that is built on the basis of the requirements of the relevant normative documents $[1,2]$.

Recent researches and publications analysis. Any QMS can be represented as a specific structure that contains four integrated systems:

- products' life cycle stages (design, production, initial control);

- monitoring, measuring, analyzing and studying for improvement;

- management responsibility, which includes a strategy and policy to achieve sustainable success;

- comprehensive resources management used at all stages of the product life cycle.

Such structure of the QMS is recommended by the current normative documentation and design practice in order to guarantee the successful work of an organization engaged in the development, manufacture and sale of machine-building products [1 - 7].

The practice shows the introduction of QMS in manufacturing firms requires not only a thorough study of the product's structure and its manufacturing technology, but also the optimal management and organization of all processes. To improve the functioning of enterprises there is a constant search for methods and tools for monitoring the quality of the production processes. As for the analysis of these processes for machine-building enterprises in $[8,9]$ it is proposed to use a matrix method for quality assessment and FMEA-analysis of types and effects of potential customer failures due to the possible defects in products and processes of its production. This ensures the establishment and correction of the possible risks that may arise during the design, production and initial control of the products.

Purpose of research. The development of the theoretical foundations for the use of FMEA analysis and matrix method for monitoring the quality of machine-building products during the following stages of its life cycle, which is associated with the formation of the requirements for the properties of basic objects.

Presentation of basic material. The FMEA-analysis is a systematic methodology for failing risk analysis that is designed to identify potential product and process failures, assess the risk associated with these types of failures, rank problems according to their importance, and to identify and implement corrective measures to address the most serious problems.

At the same time in $[8,9]$ the features of the construction of the QMS are considered, which apply to the organization of the design, development and production of complex technical products, taking into account both the specifics of technological processes and a comprehensive assessment of the peculiarities of their flow.

First, information is collected in the form of a set of partial matrix of quality about:

- designed object $\left|\left(Q_{0}\right)_{1}\right| \ldots\left|\left(Q_{0}\right)_{1 n d}\right|$;

- preparation of production $\left|\left(Q_{0}\right)_{2}\right| \ldots\left|\left(Q_{0}\right)_{2 n p}\right|$;

- technological processes $\left|\left(Q_{0}\right)_{3}\right| \ldots\left|\left(Q_{0}\right)_{n t}\right|$;

- initial control of the finished product $\left|\left(Q_{0}\right)_{s_{-} c f}\right| \ldots\left|\left(Q_{0}\right)_{S_{-} c f}\right|$; 
- factors of environmental conditions that affect the final production result $\left|\left(Q_{0}\right)_{4 \_e c}\right| \ldots\left|\left(Q_{0}\right)_{S_{m_{-}} e c}\right|$.

These matrices consist of a number of elements - quality scores (QS), each of which is a priority risk number (PRN), calculated on the expression:

$$
n_{p}=S_{d} O_{p} D_{d d}
$$

where $S_{d}$ - unitary QS (UQS) of the significance degree of the consequences of the risk;

$O_{p}$ - UQS of the probability of a defect;

$D_{d d}$ - UQS of the probability of detecting a defect.

Consequently, each partial matrix describes the list of properties: the prototype of the investigated object, the peculiarities of the formation and flow of technological production processes, factors of influence and quality of the finished product. If necessary, a set of partial matrices can be reduced to a generalized matrix of quality $\left|\left(M_{Q}\right)_{G}\right|[8]$.

The essence of monitoring the quality at any stage of an object's $t$ life cycle is to compare each partial matrix $\left|\left(Q_{0}\right)_{k-n t}\right|$ with the corresponding partial standard quality matrix $\left|\left(\left(Q_{0}\right)_{k-n t}\right)_{Q}\right|$, and in general, throughout the duration of the investigated stage of the product life cycle. The condition of violation of the object's quality will be:

$$
\left|\left(Q_{0}\right)_{k-n t}\right| \geq\left(\left|\left(Q_{0}\right)_{k-n t}\right|\right)_{Q} .
$$

It is worth noting that the deviation of even one of the QS of the partial quality matrix from the limit value of the PRN $\left(n_{p}\right)_{Q}$ is considered as a quality violation that is to be eliminated.

If the values of QS of the first matrices are obtained as a result of certain measurements, calculations or with the help of experts, then the reference matrices were still formed approximately - that is, in the form of a rough choice $\left(n_{p}\right)_{Q}$, more often the same for all elements of the matrix. According to $[4,10,11]$, it was mostly accepted $\left(n_{p}\right)_{Q}=100$, although this value did not substantiate in details and was taken arbitrarily.

In our opinion, it is advisable to develop a general approach for the formation of partial reference quality matrices, which will be based on a rational choice of the boundary values of the indicators $\left(S_{d}\right)_{Q},\left(O_{p}\right)_{Q}$ and $\left(D_{d d}\right)_{Q}$. To do this, we use the recommendations outlined in [10].

Based on the presented scales, we choose as the optimal following provisions:

- the effects of defects are considered insignificant $-\left(S_{d}\right)_{Q}$ and taken equal to 2 or 3 , depending on their weight; and also $\left(S_{d}\right)_{Q}=4$ when the consequences of the defects are weak;

- the probability of occurrence of defects is perceived relatively small $\left(O_{p}\right)_{Q}=2$ or 3 ; moderate, that is, random, but not logical $-\left(O_{p}\right)_{Q}=4$ or 5 ;

- the probability of detecting defects is high $-\left(D_{d d}\right)_{Q}$ is equal to 2 or 3 , depending on the chances of finding them; and also $\left(D_{d d}\right)_{Q}=4$ or 5 in case of noticeably high or confident chance of detection.

Thus, for each QS of a partial reference matrix, a specific value $\left(n_{p}\right)_{Q}$, is taken, which is chosen from the formed series: from 8 to 100 by the expression (1). Obviously, the highest requirements for the quality of the investigated operation, procedure or property relate to the application of value 8 . However, such an option is not always justified and feasible, primarily from an economic point of view, as it leads to unreasonable costs and an increase in the cost of production. In addition, the choice $\left(n_{p}\right)_{Q}$ also depends on the variety and specificity of the study procedure or operation.

It is recommended to set up a meeting of the enterprise experts, who propose certain values of QS for each $\left(n_{p}\right)_{Q}$, from the ones recommended above, to establish the appropriate value of the UQS of any partial reference matrix. Based on the policy of the enterprise quality, from those which are selected, one should determine $\left(n_{p}\right)_{Q}$ i and, accordingly, the whole list of necessary $\left|\left(\left(Q_{0}\right)_{k-n t}\right)_{Q}\right|$. Such expert survey is carried out using special questionnaires, in which the values of UQS, QS and partial reference matrices are 
fixed. Such expert meetings may be held periodically, depending on changes in the quality policy of the enterprise and taking into account the specifics and type of process or production procedure.

As an example, we'll take the processes of casting the cylinder sleeve AL 0908.3012.2017 of the internal combustion engine SMD-14, which is installed on tractors and combines, as well as the processes of mechanical processing of this sleeve.

Initially, the content of the partial quality matrices $\left|\left(Q_{0}\right)_{k-n t}\right|$, which are used for further analysis, is established at the expert meeting. In [9] four matrices for casting process of a cylinder sleeve are presented:

- input control (IC)

$$
\left|Q_{I C}\right|=\left|n_{p-2.2} n_{p-4.3} n_{p-4.2} n_{p-4.1}\right|,
$$

where $n_{p-2.2}-$ QS of the supporting documents on primary materials,

$n_{p-4.2}-$ QS of forced replacement of primary material,

$n_{p-4.2}-$ QS of the preliminary sorting of material,

$n_{p-4.1}-$ QS of the inaccurate selection of charge material;

- preparation of the charge $(\mathrm{PC})$

$$
\left|Q_{P C}\right|=\left|n_{p-4.2} n_{p-4.3} n_{p-3.1} n_{p-1.3} n_{p-2.5} n_{p-3.3} n_{p-1.2}\right|,
$$

where $n_{p-4.2}-$ QS of the sorting of the charge components,

$n_{p-4.3}-$ QS of the replacement of the material in the charge,

$n_{p-3.1}-$ QS of the finished container availability,

$n_{p-1.3}-$ QS of the requirements for the weight of the charge,

$n_{p-2.5}-$ QS of the mismatch of the sleeve by mechanical properties,

$n_{p-3.3}-$ QS of the untimely loading and delivery of the packaging,

$n_{p-1.2}-$ QS of the regarding the delay in the preparation of the metal;

- manufacturing and research of the sample (MRS)

$$
\left|Q_{M R S}\right|=\left|n_{p-2.2} n_{p-1.2} n_{p-4.2} n_{p-4.1} n_{p-1.3} n_{p-3.1} n_{p-4.3} n_{p-2.3} n_{p-1.3} n_{p-1.5} n_{p-2.5}\right| \text {, }
$$

where $n_{p-2.2}-$ QS of the regarding the readiness of the furnace and the bucket,

$n_{p-1.2}-$ QS of the regarding the failures and delay of the process,

$n_{p-4.2}-$ QS of the absence of hazardous substances in the sample,

$n_{p-4.1}-\mathrm{QS}$ of the constituents conformity,

$n_{p-1.3}-$ QS of the sample cast,

$n_{p-3.1}-\mathrm{QS}$ of the timely sending of the sample,

$n_{p-4.3}-$ QS of the check of the chemical composition of the sample,

$n_{p-2.3}-$ QS of the reliability of the spectral installation results,

$n_{p-1.3}-$ QS of the destruction and verification of the sample hardness,

$n_{p-1.5}-$ QS of the checking the sample microstructure,

$n_{p-2.5}-$ QS of the slag clearing;

- manufacturing of the cylinder sleeve workpiece (MW)

$$
\left|Q_{M W}\right|=\left|n_{p-2.2} n_{p-3.4} n_{p-2.5} n_{p-1.1} n_{p-4.3}\right|,
$$


where $n_{p-2.2}-$ QS of the equipment preparation (dispenser, round-rolled and coker installation and caliber),

$n_{p-3.4}-$ QS of the control of the thermal insulation paint density,

$n_{p-2.5}-$ QS of the installation of equipment regimes and cooling circuits,

$n_{p-1.1}-$ QS of the time of feeding the bucket with the liquid metal to the dispenser and the filling of the metal,

$n_{p-4.3}-$ QS of the sample control.

There are also three matrices for monitoring the processes of mechanical processing of sleeves:

- initial processing (IP)

$$
\left|Q_{I P}\right|=\left|n_{p-2.3} n_{p-1.3} n_{p-4.3} n_{p-1.3} n_{p-2.3} n_{p-4.3} n_{p-2.3} n_{p-2.4} n_{p-1.3} n_{p-4.3} n_{p-4.1} n_{p-4.3} n_{p-2.2} n_{p-3.2} n_{p-2.4}\right| \text {, }
$$

where $n_{p-2.3}-$ QS of the cutter breakage,

$n_{p-1.3}-$ QS of the length deviation of the workpiece cutting,

$n_{p-4.3}-$ QS of the bleaching of the billet in the cast iron,

$n_{p-1.3}-$ QS of the deflection of the wall size,

$n_{p-2.3}-$ QS of the hole diameter deflection,

$n_{p-4.3}-\mathrm{QS}$ of the non-compliance with the requirements for roughness,

$n_{p-2.3}-$ QS of the increasing wear on the cutter,

$n_{p-2.4}-\mathrm{QS}$ of the wrong geometry of the surface,

$n_{p-1.3}-$ QS of the wrong length of the workpiece, which causes UQS $n_{p-4.3}$,

$n_{p-4.1}-$ QS of the wrong diameter of the shirt, which causes QS $n_{p-4.5}$,

$n_{p-2.2}-$ QS of the disturbance of centering (mandibular puncture), which causes the appearance of QS of the inattention of personnel and QS $n_{p-2.4}$;

- final processing (FP)

$$
\left|Q_{F P}\right|=\left|n_{p-1.3} n_{p-2.3} n_{p-4.3} n_{p-4.4} n_{p-4.4} n_{p-1.3} n_{p-4.4} n_{p-3.1} n_{p-3.2} n_{p-3.1} n_{p-3.3} n_{p-1.5} n_{p-3.4}\right|,
$$

where $n_{p-1.3}-$ QS of the wrong height of the bunch accompanying QS $n_{p-2.3}$,

$n_{p-4.3}-$ QS of the unshielded size of the shirt, which causes the poor quality of the party from the supplier in all aspects, including its reputation $n_{p-4.4}$,

$n_{p-4.4}-$ QS of the beating increasing in the engine,

$n_{p-1.3}-$ QS of the non-observance of the radius of the duct under the boom which causes QS $n_{p-4.4}$,

$n_{p-3.1}-$ QS of the instability of microgeometric characteristics, which causes the appearance of QS due to untimely loading and provision of containers $n_{p-3.2}$,

$n_{p-3.1}-$ QS of the instability of microgeometric characteristics, which causes the appearance of QS due to untimely loading and provision of containers $-n_{p-3.3}$,

$n_{p-1.5}-$ QS of the deviations from colloidal and straightforwardness, which causes inadequate control - QS $n_{p-3.4}$;

- output control (OC)

$$
\left|Q_{O C}\right|=\left|n_{p-1.4} n_{p-4.4} n_{p-3.4} n_{p-4.4} n_{p-3.2} n_{p-3.4} n_{p-3.5}\right|,
$$

where $n_{p-1.4}-$ QS of the formation of the sleeve that causes the QS $n_{p-4.4}$, 
$n_{p-3.4}-$ QS of the undetected defect due to the critical parameters that causes QS $n_{p-4.4}$,

$n_{p-3.2}-$ QS of the lack of non-critical parameters, which causes QS associated with insufficient control $n_{p-3.4}$,

$$
n_{p-3.5}-\text { QS of the violation of the preservation and transportation conditions [9]. }
$$

Later, experts form partial reference quality matrices $\left|\left(\left(Q_{0}\right)_{k-n t}\right)_{Q}\right|$. From the theory of mathematical logic, we can assert [12] that the set of $n_{1}, n_{2}, n_{3}, \ldots, n_{48} \in N_{n}$ values $\left(n_{p}\right)_{Q}$ is an array $N_{n}$, from which experts choose the value for partial reference matrices:

$$
\text { When }\left(S_{d}\right)_{Q}=\left(S_{d}\right)_{\text {opt }} \wedge\left(O_{p}\right)_{Q}=\left(O_{p}\right)_{\text {opt }} \wedge\left(D_{d d}\right)_{Q}=\left(D_{d d}\right)_{\text {opt }} \text { to } \rightarrow\left(n_{p}\right)=\left(n_{p}\right)_{Q} \text {. }
$$

That is, based on the above recommended $\left(S_{d}\right)_{Q},\left(O_{p}\right)_{Q}$ and $\left(D_{d d}\right)_{Q}$ experts select the values that are most suitable for the particular process or procedure under investigation. With their help determined the desired $\left(n_{p}\right)_{Q}$. Despite on the similarity of QS species in different partial matrices, the reference values for them may be different, since these same types of QS characterize essentially different processes or procedures.

For example, for the investigated casting of the cylinder liners, the formed reference quality matrices will have the following form:

$$
\begin{aligned}
& -\left|\left(Q_{I C}\right)_{Q}\right|=|808010080|, \\
& -\left|\left(Q_{P C}\right)_{Q}\right|=|8064801001008080|, \\
& -\left|\left(Q_{M R S}\right)_{Q}\right|=\mid \begin{array}{ll}
10080801006480100808080100 \mid, \\
-\left|\left(Q_{M W}\right)_{Q}\right|=|80641006480|
\end{array}
\end{aligned}
$$

as for the mechanical processing of the sleeve:

$$
\begin{aligned}
& -\left|\left(Q_{I P}\right)_{Q}\right|=|648080648080806464646480808080|, \\
& -\left|\left(Q_{F P}\right)_{Q}\right|=|808080808010080806480808064|, \\
& -\left|\left(Q_{O C}\right)_{Q}\right|=|80806480646464| .
\end{aligned}
$$

Then the collection of information for FMEA-analysis about the above-mentioned processes and procedures performed during the manufacture of these cylinder liners of the internal combustion engine is carried out. As a result, as described above and in [9], there are seven particle quality matrices that characterize the stages of molding and mechanical processing of the sleeve data.

The quality level of these processes and procedures is determined on the basis of the use of the expression (2). It should be noted that there are some violations caused by the deviations of certain QS from the reference values. For example, it's about $n_{p-4.2}$ in $\left|\left(Q_{I C}\right)_{Q}\right|, n_{p-1.3}$ and $n_{p-2.5}$ in $\left|\left(Q_{P C}\right)_{Q}\right|$, $n_{p-4.3}$ in $\left|\left(Q_{P C}\right)_{Q}\right|, n_{p-1.3}$ and $n_{p-4.3} \mathrm{y}\left|\left(Q_{F P}\right)_{Q}\right|$. Thus, the risks associated with: the sorting of the charge material in size; the requirements for charge weight; the obtaining the mismatch of the sleeve at the final stage of production by mechanical properties regardless of subsequent operations; the lack or need to reconfigure the equipment during the next operations; the obtaining the wrong height of the cartridge sleeve during the turning; the defect caused by incorrect dimensions of the sleeve shirt.

In addition, the values of some elements of the received partial quality matrices coincide with the values of the corresponding elements of partial reference matrices, which indicates the minimum acceptable level of quality of these operations and procedures.

Results. Similar studies can be carried out for other stages of the life cycle, which relate to the cylinder sleeve of the internal combustion engine. That is, lists are also formed: partial quality matrices and reference quality matrices. This is due to the described above approaches, using the specifics 
and peculiarities of the processes and procedures studied, as well as the knowledge and experience of the experts to select the appropriate QSs and the necessary ones $\left(n_{p}\right)_{Q}$.

For the preparation and implementation of the production quality assessment, it has been emphasized that there is a need for a special meeting of experts, for the implementation of which will require special regulatory documents in the form of instructions for conducting and questionnaires. These documents provide the work of experts and produce relevant results.

Based on the analysis, identify the specific causes of the risks associated with the implementation of processes and procedures during the stages of the product life cycle. This allows you to work out the necessary complex of actions and measures, through which it is possible to adjust the technological processes and improve the quality of products.

Conclusions. Due to the offered approach the theoretical positions for formation of partial reference quality matrices are represented, which are used for the quality assessment of cylinder liners of internal combustion engines of agricultural machinery. This will optimize and improve the quality management system of the machine-building enterprise, as well as ensure the implementation of an effective competitive policy for the production of goods attractive to consumers.

\section{Література}

1. ISO 9001-2015. Системи управління якістю. Вимоги. [Чинний від 01.07.2016]. Київ: ДП УкрНДНЦ, 2016. 27 с.

2. ISO 9004-2012. Управління задля досягнення сталого успіху організації. Підхід на основі управління якістю. [Чинний від 01.05.2013]. Київ: ДП УкрНДНЦ, 2012. 52с.

3. Эванс Д.Р. Управление качеством / Пер. с англ. Под. ред. Э.М. Короткова. Москва : ЮНИТИ ДАНА, 2007. $671 \mathrm{c}$.

4. Кане М.М., Иванов Б.В., Корешков В.Н., Схиртладзе А.Г. Системы, методы и инструменты менеджмента качества: учеб. пособ. СПб.: Питер, 2008, 560 с.

5. Харрингтон Дж. Управление качеством в американских корпорациях. Москва : Экономика, 1990. $272 \mathrm{c}$.

6. Тито Конти, Есио Кондо, Грегори Ватсон. Качество в XXI веке. Роль качества в обеспечении конкурентоспособности и устойчивого развития/ Пер. с англ. Москва : Стандарты и качество, 2004. $280 \mathrm{c}$.

7. Тріщ Р.М., Янушкевич Д.А., Москаленко М.В., Малецька О.Є. Метрологія та стандартизація: навч. посіб. Харків : Щедра садиба плюс, 2014. 443 с.

8. Ванько В.М., Приходько О.М. Матричний метод проведення FMEA-аналізу як інструмент прогнозування якості продукції. Вимірювальна техніка та метрологія. 2017. №78. С. 80-84.

9. Ванько В.М., Приходько О.М. Вдосконалення системи управління якістю виробництва машинобудівної продукції. Праиі Одеського політехнічного університету. 2018. 1(54). С. 108-114. DOI: 10.15276/opu.1.54.2018.15.

10. IEC 60812:2006. Analysis techniques for system reliability - Procedure for failure mode and effects analysis (FMEA).

11. Панюков Д.И., Скрипачев А.В. Инженерные методы управления качеством. Анализ видов, причин и последствий потенциальных дефектов (FMEA): учеб. пособ. Тольятти : ТГУ, 2007. 133 с.

12. Манин Ю.И. Лекции по математической логике. Части 1 и 2: сов. учеб. лит-ра для ВУЗ. Москва, 1974. $204 \mathrm{c}$.

\section{References}

1. Quality management systems. Requirements. (2016). ISO 9001-2015 from $1^{\text {st }}$ July 2016. Kyiv: DP UkrNDNC.

2. Managing for the sustained success of an organization. A quality management approach. (2012). ISO 9004-2012 from $1^{\text {st }}$ May 2013. Kyiv: DP UkrNDNC.

3. Evans, D.R. (2007). Total quality. Management, organization and strategy. Moscow : UNITY DANA.

4. Kane, M.M., Ivanov, B.V., Koreshkov, V.N., \& Shirtladze, A.G. (2008). Systems, methods and tools of quality management. St. Petersburg: Allowance. 
5. Harrington, H.J. (1987). The Improvement Process how America's leading Companies improve quality. Wisconsin, USA.

6. Tito Konti, Yesio Condo, \& Gregory Watson. (2014). Quality into the 21st Century: Perspectives on Quality and Competitiveness for Sustained Performance. Moscow : Standards and quality.

7. Trish, R.M., Yanushkevich, D.A., Moskalenko ,M.V., \& Maletska, O.E. (2014). Metrology and Standardization. Kharkiv: Generous Estate Plus.

8. Vanko, V.M., \& Prikhodko, O.M. (2017). Matrix method for FMEA-analysis realization as a tool for predicting product quality. Measuring technology and metrology. 78, 80-84

9. Vanko, V.M., \& Prikhodko, O.M. (2018). Improvement of the quality management system of the machine-building production. Proceedings of Odessa Polytechnic University, 1(54), 108-114. DOI: 10.15276/opu.1.54.2018.15.

10. IEC 60812:2006. Analysis techniques for system reliability - Procedure for failure mode and effects analysis (FMEA).

11. Panyukov, D.I., \& Skripachov, A.V. (2007). Engineering methods of quality management. Analysis of types, causes and consequences of potential defects (FMEA). Tolyatti : TSU.

12. Manin, Yu.I (1974). Lectures on Math logic. Parts 1 and 2. Moscow.

Ванько Володимир Михайлович; Vanko Volodymyr, ORCID: https://orcid.org/0000-0001-6317-5906

Приходько Олександр Миколайович; Prikhodko Oleksandr, ORCID: https://orcid.org/0000-0001-8523-185X

Received September 19, 2018

Accepted October 01, 2018 